\title{
Development of Social Networking Sites and Their Role in Business with Special Reference to Facebook
}

\author{
Dr. Shree Bhagwat ${ }^{1}$, Ankur Goutam ${ }^{2}$ \\ ${ }^{1}$ (Asst. Prof. Dept. of Business Management, Dr. H.S. Gour Central University Sagar (M.P.), India) \\ ${ }^{2}$ (Faculty, Dept. of Business Management, Dr. H.S. Gour Central University Sagar (M.P.), India)
}

\begin{abstract}
The earth is huge in size whose area is $510100000 \mathrm{~km} 2$ which is divided into 243 countries worldwide and those countries have about 3200 religion and 6912 languages which are spoken by 7 billion people in world. These 7 billion people are using millions websites out of which some sites are social networking sites, as per records of these sites about 5 billion people are using social networking sites to share and transfer information and views etc. to each other also for business purposes. If we think according to the above data. So communication is not possible physically in this huge world. Here only social networking sites are making this possible. The facebook is a leading social networking site whose user are 1 billion. Facebook has won this position of population inn very short time. These social networking sites have their historical record of development and now they are facilitating various services to people and business worldwide. This paper is trying to explain the concept of social networking sites and their role in business.
\end{abstract}

Key words: Facebook, Social network, Social networking, Social Networking Sites, Social ecosystem, Social graph.

Jel Classification: $M-31, M-37$

\section{Introduction}

The dynamism of the market has been a major area of everyone's concern. The alarming shift from just "selling the products" to "being into the customers" has given marketing a different phase from "push marketing' to more of communicating with customers. Earlier the companies were connecting with the customers through radio, television, print media, bill boards and other traditional advertising. Now with a realization that the main conviction source are our colleagues, friends and our social network, where we lend our ears and mind with a personal touch and usually get persuaded taking it as more true and honest.

At the same time, technology paved the way for new possibilities. TiVo \& digital video recorders made it easy for us to bypass \& ignore commercials in live T.V. MPG players helped us listen to music \& podcast on demand, which similarly margin zed radio advertising, online retailer realized that they could increase dates by allowing visitors to their site to offer personal recommendation about products they were selling and of course, the social media industry was very successful.

It the rise of mainstream social media has proceeds one thing. It may be for providing oneself with significant identification socially. But social media today captures a lot of unusual information about users. Sometimes that mundane information can include on experience, point view or negative, with your brand or with your Company. Today everyone can connect to their own little social circle of usually a few hundred people.

People don't just hear about news, events, and so on from the local TV news broadcast and/or newspapers. People here about things from blogs, Twitter, articles, casual conservation. The term social media refers to the collection of technologies that capture communication, content, and so on across individuals, their friends, and their social naturals. Examples of social media include social networking sites like Facebook and Twitter, Blogging technologies like type pad and word press, crowed sourcing products like Wikipedia, Photo \& video sharing sites like Flicker \& You tube, \& others. These technologies help users easily create content on the Internet and share it with others. Social media is the Infrastructures that helps user to become publishers of content that is interesting to them \& their friends. The study is organized into six sections. Section - I deals with the concept, features, definition, types and classification of social network. Section - II has been devoted to a discussion of evolution and growth of social networking sites \& facebook. Section - III discusses the development of facebook \& its statistical information (data). Section - IV discusses Role of Social Networking sites in Business, Section - V discusses the Statistical Analysis of Social Networking Sites and the last Section VI specifies summary and concluding remarks.

Section-I: Concepts

1. Social Network/Networking 
Social networks are groups of people, or communities, who share a common interest, perspective, or background. The social graph is the broad collection of people, places \& Interests that makes us individual. 'Nostaligia', one of the driving force and feeling which had given social networking sites a bigger bite of everyday's meal. It keeps us connected with our friends and the memories. Many experts believe that Facebook may emerge into a "next generation social operating system". Similar to windows and the cube hogging into facebook \& other social networks is the first thing a lot of people do every day, and it will only get more important as it attracts more users.

Social networking is the grouping of individuals into specific groups, like small rural communities and neighborhood subdivision. Although social networking is possible in person, especially in the workplace, universities, colleges and high schools and it is most popular online.

This is because unlike most high schools, colleges, or workplaces, the internet is filled with millions of individuals who are looking to meet other people, to gather and share first-hand information and experiences about cooking, golfing, gardening, developing friendships professional alliances, finding employment, businessto-business marketing and even groups sharing information about baking cookies to the Thrive Movement. The topics and interests are as varied and rich as the story of our universe.

When it comes to online social networking, websites are commonly used. These websites are known as social sites. Social networking websites function like an online community of internet users. Depending on the website in question, many of these online community members share common interests in hobbies, religion, political, social and alternative lifestyles. Once you are granted access to a social networking website you can begin to socialize. This socialization may include reading the profile pages of other members and possibly even contacting them.

Another one of those benefits includes diversity because the internet gives individuals from all around the world access to social networking sites. This means that although you are in the United States, you could develop an online friendship with someone in Denmark or India. Not only will you make new friends, but you just might learn a thing or two about new cultures or new languages and learning is always a good thing.

As mentioned, social networking often involves grouping specific individuals or organizations together. While there are a number of social networking websites that focus on particular interests, there are others that do not. The websites without a main focus are often referred to as "traditional" social networking websites and usually have open memberships. This means that anyone can become a member, no matter what their hobbies, beliefs, or views are. However, once you are inside this online community, you can begin to create your own network of friends and eliminate members that do not share common interests or goals.

\subsection{Types of Social Networks}

There are three types of social media sites: the one size fits all the one-tricky pony and the hybrid.

\subsubsection{One Size Fits All}

The one-size-fits-all social network provides the user with one-stop shopping for all of their online community, entertainment, communication, and social media needs.

\subsubsection{The One-tricky Pony}

These types of social media sites try to do one thing only $\&$ to do it well. They may focus on helping you communicate to other people in a narrowly defined way. They might be widgets, or small applications, that live on other websites. They perform a single task, such as telling you what movies are playing with a certain zip code.

\subsubsection{Hybrids}

Hybrids social media websites tend to focus on one primary price of functionality but also wrap other social networking features into the platform. In many cases, the site started off as a one-tri day pony \& evolved into a hybrid due to market preserves, well requests, or other forces.

\subsection{Seven Truths of Social Networks}

A social network is only a few years old, we already know a lot about how consumers use them. Besides a few years is a generation in Internet Parlance anyway. There are seven truths of Social networks that you can rely upon.

1. Social media is preferred way of people in younger demographics to communicate with each other.

2. Social media is based on the concept of friends, but that term today is very loosely applied. Similarly, profiles are loosely defined \& can be used in a variety of way by people, companies, brands \& so on. 
3. The more active a consumer is on the Internet, the more likely they participate in multiple social networks. Oftentimes, these people are influencers within a circle of friends have a tremendous impact on the opinions of others.

4. Once Information is shared on a social network, it is out there \& can't easily be contained. Everything is out in the open \& largely visible for other people to see.

5. When building a strategy, you must think comprehensively.

6. The rules are still being made. Social media "Etiquette" is still relatively immature. Tread carefully.

7. The factors that contribute to social media usage. Everyone on social networks is motivated by some combination of the following human needs.

\subsection{New Role of Customers: Social Interactions}

The "Social" in "Social Web" implies more than technology, more then the networks where people post photos and review books: It's less about the "what" and more about "How, Why, and among whom" that distinguisher the social web from earlier, transactional online technologies. The term "Social" refers to the ways in which people connect. Friends, requiring a two way acknowledgement of a relationship are different than more casually associated followers. The term "Social" also provides insight into only they are connecting perhaps to learn something, to share on experience, or to collaborate on a project.

It is the relationships and interaction between participants that connect community members and define the social graph, a term of out that means simply who you are, who you are connected to and what you are doing. The social graph is to building relationships what ordinary links between websites are to building an information network: they define the social connections. Without the social graph without the profiles and friends, followers, and similar relations that forms between them online social communities are reduced to taskoriented, self-serve utilities much as a basic website or shopping catalog might present itself.

\subsection{SOCIAL ECOSYSTEM}

Three fundamental opportunities for understanding and leveraging the behaviours associated with collaborative interaction. These opportunities the social graph social applications, and social platforms.

\subsubsection{The Social Graph}

The social graph is the collection of lines, relationships, interaction and other connections that comprise a social network. Relationships and interactions are typically building around a set of primary participants' activities. This section course three of the primary actions: finding and following, reputation managements and moderation along with the development of conduct and use policies that are essential to maintaining a healthy, collaborative environment each of these plays a fundamental role in developing purpose driven communitiesthink support sites, supplies networks, and employee knowledge sharing and therefore, in Implementing a successful social business strategy.

\subsubsection{Social Applications}

"Social application: Software that co-ordinates group interaction that is important to running your business or organization extension to the core capabilities of the social platforms \& software services that support social networks-provide the additional, specific functionality of facebook are examples of social applications. Social applications enable the extension of relationship between a brand, product, service to the individual level by providing very specific, member selected functionality, social applications are also important is that they facilitate the overall growth of the network.

\subsubsection{Social Platforms}

Social communications and other social platforms-build around passions, life-styles, and causes or similar higher callings-provide the gathering parts for individuals interested in socializing \& collaboration in pursuit of the specific activities they enjoy together. By building a community around a passion lifestyle, or cause $\&$ then fostering and strengthening the relationships between the brand, product, or service and customers and Influences, the progression to collaborative participation and higher-level engagement is enabled.

Importantly, these three-the social graph, social application, and social platform (community) drive each other.

\subsection{Social Network/Networking Sites}

We define social network sites as web-based services that allow individuals to construct a public or semi-public profile within a bounded system, articulate a list of other users with whom they share a connection, and view and traverse their list of connections and those made by others within the system. The nature and nomenclature of these connections may vary from site to site. When we use the term "social network site" to describe this phenomenon, the term "social networking sites" also appears in public discourse, and the two terms 
are often used interchangeably. We chose not to employ the term "networking" for two reasons: emphasis and scope. "Networking" emphasizes relationship initiation, often between strangers. While network is possible on these sites, it is not the primary practice on many of them, nor is it what differentiates them from other forms of computer-mediated communication. But there is a matter of long discussion. What makes social network sites unique is not that they allow individuals to meet strangers, but rather that they enable users to articulate and make visible their social networks. This can result in connections between individuals that would not otherwise be made, but that is often not the goal, and these meetings are frequently between "latent ties" who share some offline connection. On many of the large SNSs, participants are not necessarily "networking" or looking to meet new people; instead, they are primarily communicating with people who are already a part of their extended social network. To emphasize this articulated social network as a critical organizing feature of these sites, we label them "social network sites."

\subsection{Features of Social Networking Sites}

When SNSs have implemented a wide variety of technical features, their backbone consists of visible profiles that display an articulated list of Friends' Who are also users of the system. Profiles are unique pages where one can "type oneself into being. The profile includes descriptors such as age, location, interests, and an "about me" section. Most sites also encourage users to upload a profile photo. Some sites allow users to enhance their profiles by adding multimedia content or modifying their profile's look and feel. After joining a social network site, users are prompted to identify others in the system with whom they have a relationship. The public display of connections is a crucial component of SNSs. The Friends list contains links to each Friend's profile, enabling viewers to traverse the network graph by clicking through the Friends lists. Most SNSs also provide a mechanism for users to leave messages on their Friends' profiles Beyond profiles, Friends, comments, and private messaging, SNSs vary greatly in their features and user base. Some have photo-sharing or video-sharing capabilities; others have built-in blogging and instant messaging technology. While SNSs are often designed to be widely accessible, many attract homogeneous populations initially.

\subsection{Purposes of Social Networking Sites}

Social networking sites play a big role among people to connect family and friends for various purposes which are : General, Music, Research, Games, Hospitality, Talent search, Language-learning, Blogging, Hobbies, Locating Friends, Student and Education, Social polling, photo/ video sharing, sports, movies and series (TV), travel, book lovers and books, dating medical support, teaching and learning, mobile community. Apart from these we have a long list of purposes of social networking sites. These purposes cannot be bind in list because of these are connected with social needs and feelings which have no boundaries.

\subsection{Advantages of Social Networking Sites}

We all need a network to keep in touch with people and to get know more people well, but where is the time for us to go personally and visit every one. Now it is all possible, just through these social networking sites. On line networking websites provides an easy platform that lets you stay connected with the right people or group to explore your choice of opportunities. Networking sites are great and affer huge benefits to individuals, professionals and students, they are following:

1. Facilitates open communication, leading to enhanced information discovery and delivery.

2. Allows employees to discuss ideas, post views, ask questions and share links.

3. Provides an opportunity to widen business contacts.

4. Targets a wide audience, making it a useful and effective recruitment tool.

5. Improves business reputation and client base with minimal use of advertising.

6. Expands market research, implements marketing campaigns, delivers communications and directs interested people to specific websites.

7. Social networking sites allow people to create new relationship and reconnect with friends and family.

8. Social networking sites allow for creative expression in a new medium.

9. Free messaging, blogging, photo storage, games, event invitation and many other services to any one are possible on online.

10. Social networking sites bring people with common interest together.

11. Social media helps low income kids become more familiar with computer and related technology.

12. It is cheaper to use online social networking for both personal and business use because most of it is usually free.

13. Definitely you can save the customers confidence.

14. Guaranteed meeting places.

15. Keep in touch with family as well as professional networking.

16. Staying informed about the world. 
17. Some social networking sites offer advertising to its subscribers.

18. Social networking sites offer campus surveys.

19. Practicing social skills and learning to use technology.

20. Developing independence and expressing personality.

\subsection{Disadvantages of Social Networking Sites}

Privacy and security issues are two problems that are often associated with being a member of a social network. Privacy is a huge issue since most social networking sites require that the user provide personal information. This information is on the internet and easy to access by everyone. Another issues associated with social networking is cyber bullying. Another disadvantage of social networking is that although if it is easily accessible this may be an issue especially for young teenagers and online predators that may abuse and misuse these sites. Some other disadvantages of social networking are following:

1. Social networking is time intensive.

2. Lack of feedback control.

3. Social networking sites can sell your personal information.

4. Opens up the possibility for backers to commit fraud and launch spam and virus attacks.

5. Increases the risk of people falling prey to online scams that seem genuine, resulting in data or identify theft.

6. Potentially results in lost productivity, especially if employees are busy updating profile etc.

7. Many result in negative comments from employees about the company or potential legal consequences if employees use these sites.

8. To view objectionable, illicit or offensive material.

9. Second marketing seen as intrusive.

10. Mainly attracts current grand users.

11. Lack of anonymity.

12. Compromising with in appropriate pictures, statements or other information.

13. The sites offer many time wasting activities that supplied more productive activities.

14. Teens growing up with these sites may not be aware that the information they post is public and that photos and text can be retrieved even after deletion.

15. The use of social networking sites can cause personality and brain disorders in children.

16. Cyber criminals can gather information from social networking sites.

17. Social networking sites were created to make many, not to improve people lives.

18. Sites accumulate dates about people for the purpose of selling advertising.

19. Face-to-face sacrificing has declined.

20. User of their sites frequently is proving to social isolation.

\section{Section-II: Historical development}

\subsection{Historical development of social networking sites}

According to the above definition of social network/networking, the first social network site launched in 1995. This was classmates.com. The focus of this site was school, college, work and the military. The second social network site launched in 1996 whose news was Bolt.com and focus of this site was general. In 1997, six degrees.com and Asian Avenue social network sites launched and allowed were to create profiles, list their friends and for community purposes. Care 2, open diary, gapyear.com and fatki care launched in 1998 as social network sites. In early years friends were not visible to others on sites but classmates.com allowed people to appreciate with their high school or college and sury the network for others who were also affiliated, but users could not create profile or list friends until years later. Six degrees was the first to continue these features. From 1995 to 2001, a number of community tools began supporting various combinations of profiles and publicly articulated friends. After this many sites allowed users to create personal professional and dating profiles. After this the sites allowed to contain friend's lists guest books diary pages and help people leveraging their business networks. The table no.1 is showing a complete historical record of social network site.

Table -1: Timeline of Social network sites

\begin{tabular}{|l|c|l|}
\hline S. No. & Launch Years & \multicolumn{1}{c|}{ Names of Sites } \\
\hline 1. & 1995 & Classmates.com \\
\hline 2. & 1996 & Bolt.com \\
\hline 3. & 1997 & Asianavenue,sixdegrees.com \\
\hline 4. & 1998 & care,opendiary,gapyear.com,fotki \\
\hline
\end{tabular}




\begin{tabular}{|l|c|l|}
\hline 5. & 1999 & $\begin{array}{l}\text { Advogato,cyworld,hr.com, kiwibox, vampire.freak.com, livejournal,makeout, } \\
\text { black planet }\end{array}$ \\
\hline 6. & 2000 & $\begin{array}{l}\text { English, baby!, DXY.cn, friends Reunited, hobo, deviant ART, } \\
\text { writeAPrisoner.com, maxi }\end{array}$ \\
\hline 7. & 2001 & Thinks, cozy cot, fruhstuckstreff, party flock, \\
\hline 8. & 2002 & Film affinity, footslog, fraudster, Last.fm, travellerspoint,iWiW, hub culture \\
\hline 9. & 2003 & Couch surfing, hi5, pure volume, LinkedIn, WAYN, MySpace, delicious \\
\hline 10. & 2004 & Cob, Zoo.gr, Orkut, facebook, flicker, a small world, Hyves, tagged \\
\hline 11. & 2005 & $\begin{array}{l}\text { 43Things, Buzz net, douban, focus.com, Travbuddy.com, Ning, Biip.no, } \\
\text { Bebo, librarything, blogster, mocospace }\end{array}$ \\
\hline 12. & 2006 & $\begin{array}{l}\text { anobii, crunchyroll, Patientslikeme, jaiku, Twitter, Vkontakte, GamerDNA, } \\
\text { shelfari, Cafemom, goodreads }\end{array}$ \\
\hline 13. & 2007 & $\begin{array}{l}\text { Flixster, Quechup, Tylted, virb, Geni.com, Wiser.org, eToro, weRead, Elixio, } \\
\text { Fuelmyblog, Bigadda, Fubar, Dailystrength, }\end{array}$ \\
\hline 14. & 2008 & $\begin{array}{l}\text { Cross.tv, yammer, fetlife, busuu, gays.com, academia.edu, get glue, the } \\
\text { sphere }\end{array}$ \\
\hline 15. & 2009 & Filmow, foursquare, skoob, dailybooth, fullcircle, sina weibo, \\
\hline 16. & 2010 & $\begin{array}{l}\text { Audimated.com, blauk, jiepang, laibhaari, lagbook, millatfacebook, termwiki, } \\
\text { goodwizz, diaspora*, studentscirclenetwork, }\end{array}$ \\
\hline 17. & 2011 & Faces.com, pinterest, google+, wellwer, playlist.com, \\
\hline
\end{tabular}

Source: Compiled from Wikipedia website

\subsection{Historical development of facebook}

In terms of Facebook's evolution, Facebook for business was inexorable; Facebook's ever-increasing popularity makes it an open bowl of honey to business types, who are always looking for better, easier ways to build their networks and get the word out about their products and/or services. The following table is showing its step-by-step development.

Table -2: Timeline of Facebook

\begin{tabular}{|c|c|c|}
\hline S.No. & Years & Timeline : Major events/ Major decisions \\
\hline 1 & October 28, 2003 & $\begin{array}{l}\text { Mark Zuckerberg releases Facemash, the predecessor to Facebook. It } \\
\text { was described as a Harvard University version of Hot or Not }\end{array}$ \\
\hline 2 & January 2004 & Zuckerberg begins writing Facebook \\
\hline 3. & nuary 11,2004 & ickerberg registers thefacebook.com domain. \\
\hline 4. & February 4, 2004 & Zuckerberg launches Facebook \\
\hline 5. & March 2004 & $\begin{array}{l}\text { Facebook expands to MIT, Boston University, Boston College, } \\
\text { Northeastern University, Stanford University, Dartmouth College, } \\
\text { Columbia University, and Yale University. }\end{array}$ \\
\hline 6. & April 13, 2004 & $\begin{array}{lllll}\begin{array}{l}\text { Zuckerberg, Dustin Moskovitz, and Eduardo } \\
\text { Thefacebook.com LLC, a partnership. }\end{array} & & & \text { form } \\
\end{array}$ \\
\hline 7. & June 2004 & $\begin{array}{l}\text { Facebook receives its first investment from Peter Thiel for } \\
\text { US } \$ 500,000\end{array}$ \\
\hline 8. & June 2004 & $\begin{array}{l}\text { Facebook incorporates into a new company, and Sean Parker (early } \\
\text { employee of Napster) becomes its president }\end{array}$ \\
\hline 9. & June 2004 & Facebook moves its base of operations to Palo Alto, California \\
\hline 10. & August 2004 & $\begin{array}{l}\text { To compete with growing campus-only service i2hub, Zuckerberg } \\
\text { launches Wirehog. It is a precursor to Facebook Platform applications. }\end{array}$ \\
\hline 11. & September 2004 & $\begin{array}{l}\text { ConnectU files a lawsuit against Zuckerberg and other Facebook } \\
\text { founders. }\end{array}$ \\
\hline 12. & ecember & Facebook achieves its one millionth registered user. \\
\hline 13. & May 26, 2005 & Accel Partners invests $\$ 13$ million into Facebook. \\
\hline 14. & July 19,2005 & $\begin{array}{l}\text { News Corp acquires MySpace, spurring rumors about the possible sale } \\
\text { of Facebook to a larger media company. }\end{array}$ \\
\hline 15. & August 23, 2005 & \\
\hline
\end{tabular}


Development of Social Networking Sites and Their Role in Business with Special Reference to

\begin{tabular}{|c|c|c|}
\hline 16. & September 2005 & Added high school networks \\
\hline 17. & October 2005 & Added international school networks and added photos \\
\hline 18. & 2006 & $\begin{array}{l}\text { A leaked cash flow statement shows that Facebook had a net loss of } \\
\$ 3.63 \text { million for the } 2005 \text { fiscal year. }\end{array}$ \\
\hline 19. & March 28, 2006 & $\begin{array}{l}\text { A potential acquisition of Facebook is reportedly under negotiations, } \\
\text { for } \$ 750 \text { million first, then later } \$ 2 \text { billion. }\end{array}$ \\
\hline 20. & September 2006 & $\begin{array}{l}\text { Facebook discusses with Yahoo! about the latter possibly acquiring the } \\
\text { former, for } \$ 1 \text { billion. }\end{array}$ \\
\hline 21. & September 2006 & Facebook launches a high school version of the website. \\
\hline 22. & $\begin{array}{l}\text { September } \\
26,2006\end{array}$ & $\begin{array}{l}\text { Facebook is open to everyone aged } 13 \text { and over, and with a valid email } \\
\text { address. }\end{array}$ \\
\hline 23. & June 2008 & $\begin{array}{l}\text { Facebook settles both lawsuits, ConnectU vs. Facebook, Mark } \\
\text { Zuckerberg et al. and intellectual property theft, Wayne Chang et al. } \\
\text { over The Winklevoss Chang Group's Social Butterfly project. The } \\
\text { settlement effectively had Facebook acquiring ConnectU for } \$ 20 \\
\text { million in cash and over } \$ 1.2 \text { million in shares, valued at } \$ 45 \text { million } \\
\text { based on } \$ 15 \text { billion company valuation. }\end{array}$ \\
\hline 24. & August 2008 & $\begin{array}{l}\text { Employees reportedly privately sell their shares to venture capital } \\
\text { firms, at a company valuation of between } \$ 3.75 \text { billion to } \$ 5 \text { billion. } \\
\text { Facebook sets up its international headquarters in Dublin, Ireland. }\end{array}$ \\
\hline 25. & August 2009 & Facebook acquires FriendFeed. \\
\hline 26. & September 2009 & Facebook claims that it has turned cash flow positive for the first time. \\
\hline 27. & February 2010 & $\begin{array}{l}\text { Facebook acquires Malaysian contact-importing startup Octazen } \\
\text { Solutions. }\end{array}$ \\
\hline 28. & April 2, 2010 & $\begin{array}{l}\text { Facebook announces the acquisition of photo-sharing service called } \\
\text { Divvy-shot for an undisclosed amount. }\end{array}$ \\
\hline 29. & April 19, 2010 & $\begin{array}{l}\text { Facebook introduces Community Pages, which are Pages that are } \\
\text { populated with articles from Wikipedia }\end{array}$ \\
\hline 30. & April 21, 2010 & $\begin{array}{l}\text { Facebook introduces Instant Personalization, starting with Microsoft } \\
\text { Docs, Yelp, and Pandora. }\end{array}$ \\
\hline 31. & June 2010 & $\begin{array}{l}\text { Facebook employees sell shares of the company on SecondMarket at a } \\
\text { company valuation of } \$ 11.5 \text { billion. }\end{array}$ \\
\hline 32. & October 1,2010 & $\begin{array}{l}\text { The Social Network, a film about the beginnings of Facebook directed } \\
\text { by David Fincher is released. The film is met with widespread critical } \\
\text { acclaim as well as commercial success; however, Mark Zuckerberg } \\
\text { says that the film is a largely inaccurate account of what happened. }\end{array}$ \\
\hline 33. & January 2011 & $\begin{array}{l}\$ 500 \text { million is invested into Facebook for } 1 \% \text { of the company, placing } \\
\text { its worth at } \$ 50 \text { billion. }\end{array}$ \\
\hline 34. & February 2011 & Facebook adds new "civil union" option for gay partnerships. \\
\hline 35. & February 2011 & $\begin{array}{l}\text { Facebook application and content aggregator Pixable estimates that } \\
\text { Facebook will host } 100 \text { billion photos by summer } 2011 \text {. }\end{array}$ \\
\hline 36. & June 2011 & Facebook partners with Skype to add video chat. \\
\hline 37. & September 2011 & $\begin{array}{l}\text { Facebook partners with Heroku for Facebook application development } \\
\text { using the Facebook Platform. }\end{array}$ \\
\hline 38. & September22,2011 & Facebook launches new UI Timeline in F8 Convention. \\
\hline 39. & October 10, 2011 & Facebook launches iPad app. \\
\hline 40. & December21,2011 & Facebook log in page changes due to Facebook Timeline addition. \\
\hline 41. & December22,2011 & Facebook launches its new profile user interface, Facebook Timeline. \\
\hline
\end{tabular}

Source: Compile from facebook website

\section{Section-III: The Facebook}

The facebook is a social networking site. This site contains all features of a social networking site like other social networking sites. Facebook has taken the facebook for business bull by the horns and welcomes 
facebook for business user to create Facebook pages, where business owners can "create a presence that looks and behaves like user profiles to connect and engage with your customers and amplify your voice to their friends" to create facebook ads to promote their pages.

\subsection{Introduction of Facebook}

The web address of face book is facebook.com. This is a social networking service. The face book's predecessor was opened on October 28, 2003. This was created by Mark Zuckerberg, Eduards Saverin, Andrew McCollum, Dustin Moskovitz and chats Hughes and launched in February 4, 2004. This is owned and operated by face book. Inc. This is a site of multilingual. Upto October 2012, 1 billion users are recorded which is the largest social network on the web. This organization has 4331 employees.

\subsection{Latest statistics of Facebook}

The face book is the fastest growing social networking site which pulls 1 billion people as registered facebook users. As per table no.3.United states, Brazil, India, Indonesia, Mexico, UK, Turkey, Philippines and France are the major user country of Facebook. In compare of past users only UK is showing decrease while others Countries are showing growth in No .of users and table no: 4 is showing record of face book since last 9 years.

Table -3: Top 10 Users (country) of Facebook

\begin{tabular}{|l|c|c|l|}
\hline S. No. & Name of countries & No. of past users (millions) & No. of current users (millions) \\
\hline 1. & united states & 159.0 & 167.64 \\
\hline 2. & Brazil & 54.8 & 60.74 \\
\hline 3. & India & 51.8 & 60.62 \\
\hline 4. & Indonesia & 41.0 & 50.53 \\
\hline 5. & Mexico & 36.5 & 39.42 \\
\hline 6. & United Kingdom & 37.6 & 33.23 \\
\hline 7. & Turkey & 31.3 & 31.43 \\
\hline 8. & Philippines & 28.9 & 29.87 \\
\hline 9. & France & 24.3 & 25.32 \\
\hline 10. & Germany & 23.9 & 24.99 \\
\hline 11. & Italy & 19.8 & 22.84 \\
\hline
\end{tabular}

Source: Compiled from facebook website.

Table - 4: Total user of facebook

\begin{tabular}{|l|c|c|}
\hline \multicolumn{1}{|c|}{ S. No. } & Year & No. of active users (In millions) \\
\hline 1. & 2004 & 1 million \\
\hline 2. & 2005 & 5.5 million \\
\hline 3. & 2006 & 12 million \\
\hline 4. & 2007 & 50 million \\
\hline 5. & 2008 & 100 million \\
\hline 6. & 2009 & 350 million \\
\hline 7. & 2010 & 608 million \\
\hline 8. & 2011 & 845 million \\
\hline 9. & 2012 & 1000 million \\
\hline
\end{tabular}

Source: Compiled from facebook website.

\subsection{Features of facebook}

Facebook is a social networking website. In this case the features of software and technology used by this social networking website will be features of this social networking website which separate this website from other websites. We can say these are the facilities provided to users. These features may be classified in following categories like: General features, possible additions, applications \& removed features. These categories contains the following features: Chat, credits, friend, listen with friends, facebook live, IPV6, like Google plus, messages and inbox, "Networks, groups and like pages", News feed, Notifications, Phone, Poke, Smartphone, features phones, status updates, Ticker, Timeline, URL shortener, usernames, wall, subscribe, verified accounts, Eastes eggs, pay to promote, facebook gifts, events, marketplace, Notes, Places, Platform, questions, photos, videos, security, FBML, Gifts (removed) life and deals. 


\subsection{Technology used by facebook}

Facebook is built in PHP. We can say that this is written in $\mathrm{C}++$ and PHP. Facebook is developed as one Neolithic application. The build and release process is zero downtime and new changes, to facebook are rolled out daily. Facebook used a combination platform based on $\mathrm{H}$ base to stores data across distributed machines. Facebook handles requests as AJAX behavior. Using a falling architecture, new events are stored in $\log$ files and the $\log$ s are failed. Data is read from these log files using ptail, an internally built tool to aggregate data from multiple scribe stores. Data is output in PHP format. The backend is written in Java and thript is used as the messaging formal so PHP programme can query Java services. Row logs are removed after a period of time.

\subsection{Mergers and acquisitions by facebook}

Facebook is social networking company. Each acquisition is for the respective company in its entirety, unless otherwise, specified. Most of facebook's acquisitions have been talent acquisitions and acquired products are often shutdown. Facebook has acquired 10 companies with its largest acquisition being the purchase of Instagram. The majority of the companies acquired by facebook are based in United States or around the San Francisco Bay Area. The facebook buy companies to get excellent people and acquire intellectual property. The following is the detail of mergers \& acquisitions in table No.5.

Table-5: List of mergers and acquisition by Facebook

\begin{tabular}{|c|c|c|c|c|}
\hline $\begin{array}{l}\text { S. } \\
\text { No. }\end{array}$ & Acquisition date & Company & $\begin{array}{c}\text { Used as/ } \\
\text { Integrated with }\end{array}$ & Talent acquired \\
\hline 1 & August 23, 2005 & $\begin{array}{l}\text { facebook.com domain } \\
\text { name }\end{array}$ & $\begin{array}{l}\text { name change from } \\
\text { The facebook.com }\end{array}$ & \\
\hline 2 & July 19, 2007 & Parakey & Facebook Mobile & Blake ross, joe Hewitt \\
\hline 3 & June 23, 2008 & connect U & Court settlement & none \\
\hline 4 & August 10, 2009 & Friendfeed & & $\begin{array}{l}\text { Paul buchheit, bret Taylor, Jim } \\
\text { norris, Sanjeev Singh, } 8 \text { others }\end{array}$ \\
\hline 5 & February 19, 2010 & Octazen & friend finder & 2 engineers (remote workers) \\
\hline 6 & March 2, 2010 & Divvy shot & Facebook photos & Sam Odio, Paul, Carduner \\
\hline 7 & May 13,2010 & friendster patents & & None \\
\hline 8 & May 26,2010 & Sharegrove & Facebook Groups & Kent Libbey, Adam Wolff \\
\hline 9 & July 8, 2010 & Nextstop & & $\begin{array}{l}\text { Charles Lin, Cart Sjogreen, Adrian } \\
\text { Graham }\end{array}$ \\
\hline 10 & August 15, 2010 & chai labs & & $\begin{array}{l}\text { Gokul Rajaram, Giri Rajaram, } \\
\text { others }\end{array}$ \\
\hline 11 & August 20, 2010 & hot potato & Facebook places & $\begin{array}{l}\text { Saadiq Rodgers king, Justin Shaffer, } \\
6 \text { others }\end{array}$ \\
\hline 12 & October 29,2010 & drop.io & & Sam Lessin \\
\hline 13 & $\begin{array}{c}\text { November } 15, \\
2010\end{array}$ & FB.com domain name & & \\
\hline 14 & January 25,2011 & rel8tion & & Peter Wilson \\
\hline 15 & March 2, 2011 & Beluga & $\begin{array}{l}\text { Face book } \\
\text { messenger }\end{array}$ & $\begin{array}{l}\text { Jonathan Per low, Lucy Zhang, Ben } \\
\text { Davenport }\end{array}$ \\
\hline 16 & March 20, 2011 & Snaptu & Mobile & \\
\hline 17 & March 24, 2011 & Recrec & & \\
\hline 18 & April 27, 2011 & Day tum & & Nicholas Felton, Ryan Case \\
\hline 19 & June 9, 2011 & Sofa & & $\begin{array}{l}\text { Koen Bok, Dirk Stoop, Jasper } \\
\text { Hauser, Hugo van Heuven, Jorn van } \\
\text { Dijk }\end{array}$ \\
\hline 20 & June 9, 2011 & Mailrank & & $\begin{array}{l}\text { Bryan O'Sullivan and Bethanye Mc } \\
\text { Kinney Blount }\end{array}$ \\
\hline 21 & August 2, 2011 & push pop press & & $\begin{array}{l}\text { Co-founder Mike Matas and Kimon } \\
\text { Tsinseris }\end{array}$ \\
\hline 22 & October 10,2011 & friend.ly & & \\
\hline 23 & November 8, 2011 & Strobe & $\begin{array}{l}\text { Mobile engineering } \\
\text { team }\end{array}$ & $\begin{array}{l}\text { Founder and CEO Charles Jolley, } \\
\text { other Strobe employees }\end{array}$ \\
\hline 24 & December 2, 2011 & Gowalla & & \\
\hline 25 & April 9, 2012 & Instagram & & \\
\hline 26 & April 13, 2012 & Tagtile & & Tag tile's founders \\
\hline 27 & May 5, 2012 & Glance & & Three co-founders \\
\hline 28 & May 15,2012 & Lightbox & & \\
\hline 29 & May 21,2012 & Karma & & \\
\hline
\end{tabular}


Development of Social Networking Sites and Their Role in Business with Special Reference to

\begin{tabular}{|l|l|l|l|l|}
\hline 30 & June 18, 2012 & face.com & & \\
\hline 31 & July 14, 2012 & Spool & $\begin{array}{l}\text { Mobile engineering } \\
\text { team }\end{array}$ & $\begin{array}{l}\text { Avichal Garg, Curtis Spencer, Six } \\
\text { employees }\end{array}$ \\
\hline 32 & July 20, 2012 & acrylic software & $\begin{array}{l}\text { Facebook's design } \\
\text { team }\end{array}$ & Two employees \\
\hline 33 & August 24, 2012 & Threadsy & & \\
\hline
\end{tabular}

Source: Compiled from facebook website.

\subsection{Criticism of Facebook}

Facebook has met criticism on online privacy, child safety, hate speech and the inability to terminate accounts without first manually deleting the content. The changes made by Facebook have been criticized. The electronic frontiers foundation has identified two personal information aggregation techniques called "connections" and "instead personalization" that assure anyone has access even to personal information you may not have intended to be public launching of Beacon is criticized. Other issues of criticism are: fake accounting, click fraud, environmental group, security, Better business Bureau review, interoperability and data portability, terms of use controversy, young vs facebook Inc. Paul Ceglra, Aaron Greenspum and house system, connect U. Com law suit, class action lawsuit, closed social networks, schools blocking access, organizations blocking access, Government sensorhip, students privacy concerns, effect on higher education, effect on college students grades, news feed and minifeed, corporation with Govt. search requests, complaining from CZPPIC, Duter mining, inability to voluntarily terminate A/C, memorials, customization and security, Quit facebook day, photo recognition and face lagging, investigation by the Irish data protection commissioner 2011-12, changes, Breach of privacy extended to non-members of facebook, divorce, envy. Stress, misleading campaigns, intellection property infringement, privacy infrigement, identity theft, defamation, auroxia and bulimia, advantises concerns, holoconst donial, face book hale group, promotion groups case, trolling, rape pages, disability of user A/c, enabling of harassment, lack of customer support, docontins and outages, upgrades, tracking cookies, time line, search function, breastfeeding photos, cersorston is of editorial contend and accusation of practically biased granting of group upgrades.

\subsection{The Future of Facebook}

Facebook will continue to aggressively crude in the future. So we can give some s opinion on the future of the facebook. Facebook will continue to grow its user base rapidly as it approaches 1 billion users worldwide $\&$ realizes it's potential as the gateway to the social, mobile, Interconnected Internet. The three key over where Facebook will grow is in the platform; Mobile, connect \& International. In the future of FB there will be several more companies conducting business. Facebook over the next three to four years will attempt to become the first \& last place people go when online (A partial Strategy), act as the profile "System of record" for the web, \& establish itself as on advertising Powerhouse. Mark Zuckerberg has realized that data was the king earlier then all of us. At the time he was creating FB. He knew that just how good his company would become at collecting data. Every time someone signs up for FB, they are prompted to enter almost every detail of their lives into this one website, from sex, age, occupation and relationship status to fen write movies, books \& quotes- Facebook arks users for all of the information. FB connects, brands are now able to go from being "fishers to formers" taking the Interactions they have with their customers to their website or truth. The present era is a era of online life due to which uses are increasing so that safety features will be big question due to this legal framework will improves strictly also cyber laws will be improve in future.

\section{Section-IV: Role of Social Networking sites in Business}

The explosion of social networking sites have profoundly trans formed the way people interact socially. Not surprisingly, the popularity of these sites has now made them affective to business and brands. While the lines are blurring, there are two main categories of such networking sites. The first comprises essentially "Social sites" where people collect friends, share views, post photos, update their status etc. The second category covers strictly business sites where the people join mainly to make professional contacts. Sites in the first category have struggled to build a solid business made that can monetize, make profit from their membership. One of the main reasons for this is the sites basically social architecture. Ironically, some big corporations and governments are still disciplining or dismissing employees for using social networking sites at the office- usually citing time wasting. But as companies realize that social media tools can boost productively and increase profits, values and attitudes about web platforms are changing. Members are the commodity for some revenues by selling information about its members to companies is possible by social networking began as the province of individuals, businesses are now trying to capitalize on this trend as they search for specific strategies and tactics to derive value from it. Social networking sites can enable marketing professionals, sales people and customer service agents to develop meaningful relationship with customer in new way. But the true value from social networking cannot be achieved in isolation. Rather, organizations need to take stock of their core business 
process and customer management initiatives and identity how social networking can further enhance and extend those initiatives on the basis of the post experiences the power of this new media to accelerate the business can be counted as the benefits to the business.

\subsection{Benefits of Social Networking Sites to Business:}

1. Increased awareness of the organization.

2. Increased traffic to website.

3. Greater favorable perceptions of the brand.

4. Able to monitor conversations about the organization.

5. Able to develop targeted marketing activities.

6. Better understanding of customer's perceptions of their brand.

7. Improved insights about their target markets.

8. Identification of positive and negative comments.

9. Increase in new business.

10. Identification of new product or service opportunities.

11. Ability to measure the frequency of the discussion about brand.

12. Early warning of potential product or service issues.

13. Reduce cost to reach customers.

14. Online brand and strong trust bulling.

15. Have a curreed ineg of the company.

16. Open channels with customers.

17. Contributes to a good ranking in search origins.

18. It is relatively cheap.

19. To search customers.

20. Branding \& Networking opportunities.

21. Interaction with public \& attracting traffic.

22. Increase access to customer services and feedback.

23. Facilitate in expansion of your business network.

24. Build up your online reputation \& Link popularity.

\section{Section-V: Statistical Analysis of Social Networking Sites.}

Alexa. Com is the web information company. As per its statistics 500 web sites are recorded as top most websites. As per this record 200 websites are identified as social networking sites about 5 billion people are using these sites while the total population of world is 7 billion. This is a big portion of Total population of the world.

Table No.1 of this paper is showing the timeline of social networking site. According to this table first social networking site was launched in 1995 and today we have thousand and thousand sites. The facebook is a leading website. This site was launched in 2003, at present 1 billion users are registered with this sites other relevant feature about facebook is timeline and is given in table No.2. Top 10 countries, who is using facebook is given in Table No. 3 and Table No.4 is showing the increase at facebook users since last 9 years. Table No.5 is explaining the detail of merger and acquisition by facebook.

The Table No.6 is showing the Top 10 social networking sites of world where as table No.7 showing top 10 countries who are mostly engaged on social is networking sites. The record of top 50 countries of world is given in table No.8 who are using facebook. Table No.9 is showing the detail No of facebook users in Indian city (major) and Table No 10 is showing some important information about facebook site.

Table - 6: Top10 social networking sites of world

\begin{tabular}{|l|c|c|}
\hline S. No. & Name of Site & Registered users \\
\hline 1. & Facebook & 1000 \\
\hline 2. & Twitter & 517 \\
\hline 3. & Qzone & 480 \\
\hline 4. & Google+ & 400 \\
\hline 5. & Sina weibo & 300 \\
\hline 6. & Habbo & 268 \\
\hline 7. & Renren & 160 \\
\hline 8. & Linkedin & 160 \\
\hline 9. & Vkontakte & 123 \\
\hline 10. & Bebo & 117 \\
\hline
\end{tabular}

Source: Compiled from silverpop.com 
Table- 7: Top 10 most engaged countries for social networking:

\begin{tabular}{|l|c|c|}
\hline S. No. & Name of Country & Average hours per month \\
\hline 1 & Israel & 11.1 \\
\hline 2 & Argentina & 10.7 \\
\hline 3 & Russia & 10.4 \\
\hline 4 & Turkey & 10.2 \\
\hline 5 & Chile & 9.8 \\
\hline 6 & The Philippines & 8.7 \\
\hline 7 & Colombia & 8.5 \\
\hline 8 & Peru & 8.3 \\
\hline 9 & Venezuela & 7.9 \\
\hline 10 & Canada & 7.7 \\
\hline 11 & United States & 7.6 \\
\hline
\end{tabular}

Source: Compiled from statisticbrain.com

Table-8: Top 50 countries on facebook (country wise users of facebook in world)

\begin{tabular}{|c|c|c|c|c|c|}
\hline $\begin{array}{l}\text { S. } \\
\text { No. }\end{array}$ & $\begin{array}{l}\text { Name of } \\
\text { country }\end{array}$ & $\begin{array}{l}\text { Number of } \\
\text { users(millions) }\end{array}$ & S. No. & Name of country & $\begin{array}{l}\text { Number of } \\
\text { users(millions) }\end{array}$ \\
\hline 1. & United states & 167.64 & 26. & Vietnam & 9.43 \\
\hline 2. & Brazil & 60.74 & 27. & South Korea & 9.37 \\
\hline 3. & India & 60.62 & 28. & Pakistan & 7.49 \\
\hline 4. & Indonesia & 50.53 & 29. & Netherland & 7.34 \\
\hline 5. & Mexico & 39.42 & 30. & Russia & 7.15 \\
\hline 6. & $\begin{array}{c}\text { United } \\
\text { Kingdom }\end{array}$ & 33.23 & 31. & Nigeria & 6.71 \\
\hline 7. & Turkey & 31.43 & 32. & South Africa & 6.55 \\
\hline 8. & Philippines & 29.87 & 33. & Saudi Arabia & 5.86 \\
\hline 9. & France & 25.32 & 34. & Romania & 5.10 \\
\hline 10. & Germany & 24.99 & 35. & Ecuador & 5.08 \\
\hline 11. & Italy & 22.84 & 36. & Morocco & 4.92 \\
\hline 12. & Argentina & 20.43 & 37. & Sweden & 4.90 \\
\hline 13. & Canada & 18.59 & 38. & Belgium & 4.87 \\
\hline 14. & Colombia & 17.48 & 39. & Portugal & 4.62 \\
\hline 15. & Thailand & 17.47 & 40. & Hungary & 4.22 \\
\hline 16. & Spain & 17.34 & 41. & Hong Kong & 4.06 \\
\hline 17. & Japan & 16.36 & 42. & Greece & 3.88 \\
\hline 18. & Malaysia & 13.22 & 43. & Algeria & 3.86 \\
\hline 19. & Taiwan & 13.06 & 44. & Czech Republic & 3.79 \\
\hline 20. & Australia & 11.72 & 45. & Israel & 3.78 \\
\hline 21. & Egypt & 11.63 & 46. & Serbia & 3.35 \\
\hline 22. & Venezuela & 10.00 & 47. & $\begin{array}{l}\text { United Arab } \\
\text { Emirates }\end{array}$ & 3.30 \\
\hline 23. & Chile & 9.75 & 48. & Bangladesh & 3.29 \\
\hline 24. & Peru & 9.58 & 49. & Tunisia & 3.25 \\
\hline 25. & Poland & 9.44 & 50. & Swaziland & 3.02 \\
\hline
\end{tabular}

Source: Compiled from socialbakers.com

Table- 9: City wise (major) users of facebook in India

\begin{tabular}{|l|c|c|c|c|}
\hline S. No. & $\begin{array}{l}\text { Name of major City in } \\
\text { India }\end{array}$ & $\begin{array}{l}\text { No. of } \\
\text { users }\end{array}$ & $\begin{array}{c}\text { \% share in India } \\
\mathbf{( 6 0 . 6 2} \text { million) }\end{array}$ & $\begin{array}{c}\text { \% share in India } \\
\mathbf{1} \text { billion }\end{array}$ \\
\hline 1 & Delhi & $5,123,180$ & 8.45 & 0.51 \\
\hline 2 & Mumbai & $4,372,360$ & 7.21 & 0.43 \\
\hline 3 & Bangalore & $3,076,260$ & 5.07 & 0.30 \\
\hline 4 & Hyderabad & $2,284,340$ & 3.76 & 0.22 \\
\hline 5 & Chennai & $2,195,760$ & 3.62 & 0.21 \\
\hline
\end{tabular}


Development of Social Networking Sites and Their Role in Business with Special Reference to

\begin{tabular}{|c|c|c|c|c|}
\hline 6 & Pune & $1,913,640$ & 3.15 & 0.19 \\
\hline 7 & Kolkata & $1,591,120$ & 2.62 & 0.15 \\
\hline 8 & Ahmadabad & $8,92,560$ & 1.47 & 0.89 \\
\hline 9 & Jaipur & 752,260 & 1.24 & 0.075 \\
\hline 10 & Chandigarh & 670,500 & 1.10 & 0.067 \\
\hline 11 & Lucknow & 608,120 & 1.00 & 0.060 \\
\hline 12 & Surat & 508,360 & 0.83 & 0.050 \\
\hline 13 & Indore & 503,020 & 0.82 & 0.0503 \\
\hline 14 & Nagpur & 423,080 & 0.69 & 0.042 \\
\hline 15 & Bhopal & 423,000 & 0.69 & 0.0423 \\
\hline 16 & Ludhiana & 411,820 & 0.67 & 0.0411 \\
\hline 17 & Coimbatore & 390,460 & 0.64 & 0.039 \\
\hline 18 & Vadodara & 351,260 & 0.57 & 0.035 \\
\hline 19 & Jalandhar & 309,160 & 0.51 & 0.0309 \\
\hline 20 & Kanpur & 307,160 & 0.50 & 0.0307 \\
\hline 21 & Patna & 292,900 & 0.48 & 0.029 \\
\hline 22 & Thiruvananthapuram & 288,160 & 0.47 & 0.028 \\
\hline 23 & Kochi & 266,620 & 0.43 & 0.026 \\
\hline 24 & Guwahati & 248,860 & 0.41 & 0.024 \\
\hline 25 & Rajkot & 241,500 & 0.39 & 0.0241 \\
\hline 26 & Dehradun & 237,760 & 0.39 & 0.023 \\
\hline 27 & Amritsar & 234,840 & 0.38 & 0.0234 \\
\hline 28 & Nasik & 232,660 & 0.38 & 0.0232 \\
\hline 29 & Noida & 217,360 & 0.35 & 0.0217 \\
\hline 30 & Srinagar & 214,640 & 0.35 & 0.0214 \\
\hline 31 & Ghaziabad & 213,680 & 0.35 & 0.021 \\
\hline 32 & Allahabad & 206,100 & 0.33 & 0.020 \\
\hline 33 & Ranchi & 190,980 & 0.31 & 0.019 \\
\hline 34 & Bhubaneswar & 190,500 & 0.31 & 0.0190 \\
\hline 35 & Varanasi & 189,260 & 0.31 & 0.018 \\
\hline 36 & Jammu & 187,600 & 0.30 & 0.0187 \\
\hline 37 & Agra & 181,340 & 0.29 & 0.0181 \\
\hline 38 & Visakhapatnam & 177,140 & 0.29 & 0.0177 \\
\hline 39 & Faridabad & 173,280 & 0.28 & 0.0173 \\
\hline 40 & Aurangabad & 172,040 & 0.28 & 0.0172 \\
\hline 41 & Meerut & 162,380 & 0.26 & 0.0162 \\
\hline 42 & Mangalore & 155,360 & 0.25 & 0.0155 \\
\hline 43 & Jabalpur & 151,160 & 0.24 & 0.0151 \\
\hline 44 & Raipur & 150,220 & 0.24 & 0.0150 \\
\hline 45 & Vijayawada & 144,860 & 0.23 & 0.0144 \\
\hline 46 & Gwalior & 143,780 & 0.23 & 0.0143 \\
\hline 47 & Kota & 142,000 & 0.23 & 0.0142 \\
\hline 48 & Mysore & 131,800 & 0.21 & 0.0131 \\
\hline 49 & Madurai & 130,760 & 0.21 & 0.0130 \\
\hline 50 & Udaipur & 125,520 & 0.20 & 0.0125 \\
\hline 51 & Jodhpur & 91,060 & 0.15 & 0.009 \\
\hline 52 & Bareilly & 89,940 & 0.14 & 0.0089 \\
\hline 53 & Siliguri & 82,740 & 0.13 & 0.0082 \\
\hline 54 & Aligarh & 82,120 & 0.13 & 0.00821 \\
\hline 55 & Cuttack & 78,940 & 0.13 & 0.0078 \\
\hline 56 & Shillong & 70,740 & 0.11 & 0.0070 \\
\hline 57 & Moradabad & 70,480 & 0.11 & 0.0070 \\
\hline 58 & Solapur & 65,120 & 0.10 & 0.0065 \\
\hline 59 & Bilaspur & 61,120 & 0.10 & 0.0061 \\
\hline
\end{tabular}

Source: Compiled from statisticbrain.com 
Table-10: Recent Statistics of facebook

\begin{tabular}{|l|l|l|}
\hline S. No. & \multicolumn{1}{|c|}{ Particulars } & \multicolumn{1}{c|}{ Data } \\
\hline 1 & Total number of facebook users worldwide & 1 billion \\
\hline 2 & Total percentage of 18-24 year olds who already use social media & $98 \%$ \\
\hline 3 & Total percentage of people on Earth who use facebook & $11 \%$ \\
\hline 4 & Total amount of minutes people spend on facebook every month & 700 billion \\
\hline 5 & Average amount of time a person uses facebook per month & 15 hours 33 minutes \\
\hline 6 & Total amount of people who access facebook with phone & 250 million \\
\hline 7 & Total amount of websites that have integrated with facebook & 2.5 million \\
\hline 8 & Total pieces of content shared on facebook each month & 70 billion \\
\hline 9 & percent of teenagers who log on to facebook over 10 times per day & $22 \%$ \\
\hline 10 & percent of facebook users under the age of 10 & $25 \%$ \\
\hline
\end{tabular}

Source: compiled from statisticbrain.com

\section{Section-VI: Conclusions}

The Social technology connects people in ways that facilitate sharing information and other things to each other. In very short time. The social sites dramatically levels the playing field by making information plentiful, just as it also levels business and organizations that operate on the principles as making information scarce. Today every marketer throws they need to be on social network site to gave advantages. Over the past 8 years, the social media business has grown from a sleepy, sophomoric way for people to communicate to perhaps the future of how they will share information and bring their of line lives online. It is truly been amazing to see how much the internet business has evolved as result of social media technologies. Due to this social relationship were becoming more and more transparent and they were moving online. Here computer usage is a pervasive part of our lives. It is hard to olive that was not just a little more than a generation ago. The social media is the latest big thing in marketing. The data have show in Table No.-1,2,3,4,5,6,7,8,9\&10 of this paper are showing how this social networking sites are developing and providing facilities to the people and business organizations. Their popularity in short time is representing their need in society for communication as well as for business.

\section{Journal Papers:}

\section{References}

[1] Dr. Biswajit Das, Jyoti Shankar Sahoo, Social Networking Sites - A Critical Analysis of Its Impact on Personal and Social Life, International Journal of Business and Social Science Vol. 2 No. 14

[2] P. Sri Jothi, M. Neelamalar and R. Shakthi Prasad, Analysis of social networking sites: A study on effective communication strategy in developing brand communication, Journal of Media and Communication Studies Vol. 3(7), pp. 234-242, July 2011

[3] Vivek bajpai, Dr. Sanjay Pandey, Viral Marketing Through Social Networking Sites With Special Reference of facebook, IRJC International Journal of Marketing, Financial Services \& Management Research Vol.1 Issue 7, July 2012, ISSN 2277

\section{Books:}

[4] Chaffey D, Internet Marketing, Strategy, Implementation and Practice (Pearson Education Limited, 2003)

[5] Donath J, Boyd D, Public displays of connection (BT Technol. J., 2004)

[6] Scott DM, The New Rules of Marketing and PR. (John Wiley \& Sons Inc., 2009)

[7] Shih C, The Facebook Era. Tapping online social networks to build better products, reach new audiences and selling more stuff (Prentice Hall Publication, 2009)

[8] Weber L, Marketing to the Social Web. Second Edition (John Wiley and Sons, 2009)

[9] Dave Evans with Jake McKee, Social Media Marketing: The Next Generation of Business Engagement (John Wiley and Sons, 2011)

[10] Chris Treadaway \& Mari Smith, Facebook Marketing: An Hour a Day, (John Wiley and Sons, 2011)

\section{Websites:}

[11] "List of Social network sites" www.wikipedia.com (accessed on Nov. 25,2012)

[12] "Timeline of Facebook", "Top 10 Users (country) of Facebook", "Total user of facebook", "List of mergers and acquisition by Facebook", www.facebook.com (accessed on Nov. 25,2012)

[13] Top10 social networking sites of world" www.silverpop.com (accessed on Nov. 26,2012)

[14] "Top 10 most engaged countries for social networking", "City wise (major) users of facebook in India", "Recent Statistics of facebook" www.statisticbrain.com (accessed on Nov. 26,2012)

[15] "Top 50 countries on facebook (country wise users of facebook in world)" www.socialbakers.com (accessed on Nov. 28,2012) 